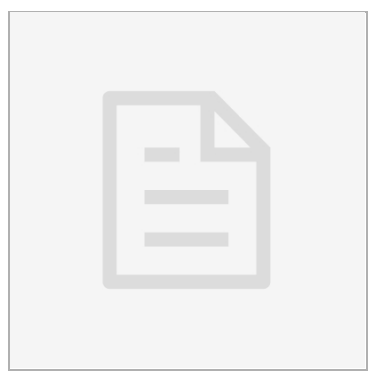

APR 24, 2018

\section{OPEN ACCESS}

DOI:

dx.doi.org/10.17504/protocol s.io.n7bdhin

\section{External link:}

http://expansionmicroscopy.or g

Collection Citation: Fei

Chen, Asmamaw T Wassie,

Allison J Cote, Anubhav Sinha,

Shahar Alon, Shoh Asano,

Evan R Daugharthy, Jae-Byum

Chang, Adam Marblestone,

George M Church, Arjun Raj,

Edward S Boyden 2018.

ExFISH Protocols For Cells and Tissues. protocols.io

https://dx.doi.org/10.17504/p

rotocols.io.n7bdhin

\section{MANUSCRIPT CITATION:}

Chen F. (2016). Nanoscale

imaging of RNA with

expansion microscopy. Nature

Methods 13, 679-684

(2016) doi: $10.1038 /$ nmeth. 3

$\underline{899}$

License: This is an open

access collection distributed under the terms of

the Creative Commons

Attribution License, which

permits unrestricted use, distribution, and reproduction

in any medium, provided the original author and source are credited

\section{Protocol status: Working} We use this protocol and it's working

Created: Apr 02, 2018

Last Modified: Apr 24, 2018

COLLECTION integer ID: 11203

\title{
(3) ExFISH Protocols For Cells and Tissues
}

Fei Chen ${ }^{1}$, Asmamaw T Wassie ${ }^{1}$, Allison J Cote ${ }^{2}$, Anubhav Sinha ${ }^{1}$, Shahar Alon ${ }^{1}$, Shoh Asano ${ }^{1}$, Evan R Daugharthy ${ }^{3}$, Jae-Byum Chang ${ }^{1}$, Adam Marblestone ${ }^{1}$, George M Church ${ }^{3}$, Arjun Raj ${ }^{2}$, Edward S Boyden ${ }^{1}$

${ }^{1}$ Massachusetts Institute of Technology; ${ }^{2}$ University of Pennsylvania; ${ }^{3}$ Harvard University

Human Cell Atlas Method Development Community

Ed Boyden

\section{ABSTRACT}

These are Expansion FISH (ExFISH) protocols for super-resolution imaging of RNA structure and location with diffractionlimited microscopes.

Please select the appropriate protocol depending on your sample (cells or tissue). 


\section{Protocol}

\section{NAME}

ExFISH - Cultured Cells

\section{VERSION 1}

CREATED BY

Ed Boyden

\section{Protocol}

NAME

y ExFISH - Tissue Slice

\section{VERSION 1}

CREATED BY

Ed Boyden

OPEN $\rightarrow$ 